\title{
Distribution and habitat associations of the Critically Endangered frog Walkerana phrynoderma (Anura: Ranixalidae), with an assessment of potential threats, abundance, and morphology
}

\author{
Arun Kanagavel, ${ }^{1}$ Sethu Parvathy, ${ }^{1}$ Abhiijth P. Chundakatil, ${ }^{2}$ Neelesh Dahanukar, ${ }^{3}$ and Benjamin \\ Tapley $^{4}$ \\ ${ }^{1}$ Conservation Research Group, St. Albert's College, Banerji Road, Kochi, Kerala, 682 018, India. \\ E-mail: arun.kanagavel@gmail.com. \\ ${ }^{2}$ Department of Ecology and Environmental Sciences, School of Life Sciences, Pondicherry University, Pudhucherry, 605014 , \\ India. \\ ${ }^{3}$ Indian Institute of Science Education and Research, G1 Block, Dr. Homi Bhabha Road, Pashan, Pune, 411008 , India. \\ ${ }^{4}$ Zoological Society of London, Regent's Park, London, NW1 4RY, United Kingdom.
}

\begin{abstract}
Distribution and habitat associations of the Critically Endangered frog Walkerana phrynoderma (Anura: Ranixalidae), with an assessment of potential threats, abundance, and morphology. Little is known about Walkerana phrynoderma, a frog endemic to the Anamalai Hills of the Western Ghats of India. Baseline information (i.e., distribution, threats, habitat characteristics, activity patterns, and relative abundance) is provided for this species, with the aim of improving our understanding of the status of the species in the wild. Visual-encounter, transect, and time-activity budget surveys were conducted in and around the Anamalai Hills of the Western Ghats. The frog skin was swabbed to determine the presence/absence of Batrachochytrium dendrobatidis, and habitat and environmental characteristics were recorded at sites where W. phrynoderma was found. These data were compared with those of sites apparently lacking this species that had suitable habitat. Walkerana phrynoderma is restricted to evergreen forests between 1300 and $1700 \mathrm{~m}$ a.s.l. in the Anamalai Tiger Reserve and at Munnar; thus, its range was extended from the state of Tamil Nadu to the adjoining state of Kerala. Pesticide runoff and human disturbance are the most severe threats to the species; $B$. dendrobatidis was not detected. This nocturnal anuran prefers forest edges and is associated with well-shaded forest floors in cool areas near freshwater streams. Walkerana phrynoderma is rarely encountered whereas its congener, W. leptodactyla, is more common. The impact of anthropogenic disturbances, especially waste disposal and development of tourism infrastructure, should be evaluated. The land that is owned by the Forest Department peripheral to the protected areas could be designated as eco-sensitive sites to prevent changes in land use that could have an adverse effect on $W$. phrynoderma.
\end{abstract}

Received 28 July 2017

Accepted 28 February 2018

Distributed June 2018 
Keywords: amphibian, Anamalai Hills, Cardamom Hills, EDGE species, Indirana phrynoderma, Sallywalkerana phrynoderma.

\begin{abstract}
Resumo
Distribuição e associações de habitat do anuro Criticamente Ameaçado Walkerana phrynoderma (Anura: Ranixalidae), com uma avaliação das ameaças potenciais, abundância e morfologia. Pouco se sabe sobre Walkerana phrynoderma, um anuro endêmico dos Montes Anamalai dos Ghats Ocidentais da Índia. Com o objetivo de aumentar nosso conhecimento do status da espécie na natureza, fornecemos informações básicas (i.e., distribuição, ameaças, características do habitat, padrões de atividade e abundância relativa). Foram feitas investigações por encontro visual, transectos e orçamento temporal no interior e entorno dos Montes Anamalai dos Ghats Ocidentais. A secreção da pele dos animais foi amostrada para determinar a presença/ausência de Batrachochytrium dendrobatidis, e foram registradas as características do habitat e do ambiente nos locais onde $W$. phrynoderma foi encontrada. Esses dados foram comparados com os dos locais em que a espécie estava aparentemente ausente. Walkerana phrynoderma está restrita às florestas perenifolias situadas entre 1300 e 1700 m a.s.l. na Reserva Anamalai Tiger e em Munnar; dessa forma, sua distribuição foi extendida do estado de Tamil Nadu para o estado vizinho de Kerala. As ameaças mais severas a essa espécia são o uso de pesticidas e perturbações antrópicas; $B$. dendrobatidis não foi detectado. Esse anuro norturno prefere bordas florestais e está associado com chãos de florestas bem sombreadas em áreas frescas próximo a riachos. Walkerana phrynoderma é raramente encontrada, enquanto sua congênere, $W$. leptodactyla, é mais comum. O impacto de perturbações antropogênicas, especialmente deposição de lixo e desenvolvimento de infraestrutura turística, deveria ser avaliado. A área de propriedade do Departamento de Florestas na periferia das áreas protegidas poderia ser designada como locais ecossensíveis para prevenir mudanças no uso da terra que pudessem ter um efeito adverso sobre $W$. phrynoderma.
\end{abstract}

Palavras-chave: anfíbio, espécie-EDGE, Indirana phrynoderma, Montes Anamalai, Montes Cardamom, Sallywalkerana phrynoderma.

\section{Introduction}

Amphibians are the most threatened vertebrate taxon as evidenced by their rapid global declines as a result of habitat loss, climate change, and infectious disease (Stuart et al. 2004, Skerratt et al. 2007, Sodhi et al. 2008, Baillie et al. 2010, Hoffmann et al. 2010). Most amphibian species (53.8\%) occur in 25 biodiversity hotspots (Myers et al. 2000). The biodiversity hotspot of Western Ghats and Sri Lanka is one of the eight "hottest" hotspots as determined by high endemic species-to-area ratio and ongoing habitat loss. About $89 \%$ of the 229 amphibian species known from the Western Ghats of India are endemic (Frost 2017, Kanagavel et al. 2017a). This mountain range is a reservoir of unparalleled evolutionary history having served as Cenozoic refugium by providing ideal environment to the endemic genera such as Micrixalus, Nyctibatrachus, and Walkerana (Roelants et al. 2003, Dahanukar et al. 2016).

Ranixalidae Dubois, 1987 comprises two genera, Indirana and Walkerana, both of which are endemic to peninsular India (Dahanukar et al. 2016, Garg and Biju 2016). Ranixalid frogs are terrestrial, and associated with riparian, leaflitter habitats in tropical wet, evergreen, and semi-evergreen forests (Nair et al. 2012). They have well-developed toe pads that enable them to adhere to wet rock surfaces where they breed in streams. They lay terrestrial eggs and have semi-terrestrial tadpoles that cling on to wet surfaces of steep rocks and trees (Roelants et al. 2003, Tapley et al. 2011, Gaitonde and Giri 2014). The three currently recognized species of 
Walkerana occur south of the Palghat Gap, a major biogeographical barrier in the Western Ghats, and are threatened by loss of habitat as a result of land-use changes, road development, and harvesting of timber and firewood (Biju et al. 2004a, b, Biju and Dutta 2004, Dahanukar et al. 2016, IUCN 2017). Additionally, Batrachochytrium dendrobatidis Longcore, Pessier and D. K. Nichols, 1999 (Bd), which causes chytridomycosis, a disease associated with global amphibian population declines (Skerratt et al. 2007), has been reported from the Western Ghats (Nair et al. 2011, Dahanukar et al. 2013, Molur et al. 2015). Bd has been detected in two ranixalid frog species, Indirana brachytarsus (Günther, 1876) and I. leithii (Boulenger, 1888) (Nair et al. 2011, Dahanukar et al. 2013, Molur et al. 2015). Amphibian declines associated with this pathogen have not been reported in India; however, there has been relatively little longitudinal monitoring of amphibian populations in the region.

Walkerana phrynoderma (Boulenger, 1882) is Critically Endangered and assessed as a global priority for amphibian conservation owing to its evolutionary distinctiveness (Biju et al. 2004a, Isaac et al. 2012). The presence of the species is confirmed by only one record in the Anamalai Hills of the Western Ghats where its range is less than $100 \mathrm{~km}^{2}$. The locality is the Anamalai Tiger Reserve and its surroundings (previously known as Indira Gandhi Wildlife Sanctuary) (Biju et al. 2004a, Garg and Biju 2016); another locality record (Dahanukar et al. 2016) probably is erroneous. Because of the presence of this frog, the Anamalai Tiger Reserve has been designated as one of 18 Alliance for Zero Extinction sites in India (AZE 2013).

Virtually nothing is known about the ecology, behavior, or morphology of this species, which is known only from five individuals (Dahanukar et al. 2016, Garg and Biju 2016). Reportedly, the elevational distribution is between 500 and 1750 $\mathrm{m}$ a.s.l. and the maximum snout-vent length (SVL) is $33.0 \mathrm{~mm}$ (Boulenger 1890, Biju et al. 2004a, Dahanukar et al. 2016, Garg and Biju
2016). The frog is thought to be threatened by local residents who collect wood for fuel (Biju et al. 2004a). Our goal is to generate baseline data (e.g., distribution, relative abundance, morphology, habitat preference, abiotic factors affecting distribution) for Walkerana phrynoderma, including potential threats to its existence to inform conservation management.

\section{Materials and Methods}

\section{Study Area}

The Anamalai Tiger Reserve is $958 \mathrm{~km}^{2}$ in the state of Tamil Nadu with elevations ranging from 100-2659 $\mathrm{m}$ a.s.l. The vegetation varies from tropical evergreen to scrub and thorn forest (Kumaraguru et al. 2011, Rameshan et al. 2014). Munnar is a popular tourist destination with an area of $557 \mathrm{~km}^{2}$ in the state of Kerala at an elevation of $1600 \mathrm{~m}$ a.s.l.; it adjoins the Anamalai Tiger Reserve. Munnar is within the jurisdiction of the Munnar Wildlife Division and Munnar Forest Division, that manage protected areas (PAs) and reserve forests in the region that occur across elevations of 1400 and $2600 \mathrm{~m}$ a.s.l. Most of the land composing Munnar, as well as parts of the Anamalai Tiger Reserve around Valparai, have been converted to tea, coffee, cardamom, and Eucalyptus plantations that are interspersed with fragments of tropical evergreen forests (Raman and Mudappa 2003). In Valparai, these plantations occupy $220 \mathrm{~km}^{2}$, whereas the forest fragments cover about $100 \mathrm{~km}^{2}$ (Raman and Mudappa 2003, Sridhar et al. 2008). The area has a rich anuran assemblage, with several new frogs-e.g., Micrixalus nelliyampathi Biju, Garg, Gururaja, Shouche, and Walukar, 2014, M. frigidus Biju, Garg, Gururaja, Shouche, and Walukar, 2014, M. adonis Biju, Garg, Gururaja, Shouche, and Walukar, 2014, Raorchestes chlorosomma (Biju and Bossuyt, 2009), R. munnarensis (Biju and Bossuyt, 2009), $R$. resplendens Biju, Shouche, Dubois, Dutta, and Bossuyt, 2010, and Nyctibatrachus poocha Biju, Van Bocxlaer, Mahony, Dinesh, Radhakrishnan, 
Zachariah, Giri, and Bossuyt, 2011-having been discovered recently (Biju and Bossuyt 2009, Biju et al. 2010, 2011, 2014).

\section{Site-based Survey}

Visual-encounter surveys were undertaken by three to six persons who actively searched terrestrial habitats between 08:45 and 20:30 h across the known species range of Walkerana phrynoderma (Anamalai Tiger Reserve) and adjoining areas (Munnar) to determine exact locations where the species occurred (Figure 1). We opportunistically chose 38 locations to survey as much of the study area as possible across the different habitats and elevations (600$2100 \mathrm{~m}$ a.s.l.). These surveys totaled 108.8 person.hr and were conducted in Tamil Nadu (22 locations) in 2013 and at Kerala (16 locations) in 2014 during monsoon seasons (i.e., southwest monsoon from May-August; northeast monsoon from October-December). We recorded the anurans encountered at each site and, when possible, identified the genus and species. Weather parameters, habitat type, elevation, habitat-level threats, and total survey time were also recorded (Table 1). We used a Garmin GPS $62 \mathrm{~S}$ to determine geographical coordinates and elevation, and a digital thermometer (Eurolab, to the nearest $0.1^{\circ} \mathrm{C}$ ) to measure air and soil temperatures. We measured relative humidity with a digital hygrometer (TempTec CTH 288, to the nearest $1 \%$ ). We collected water samples from the closest body of water at each location

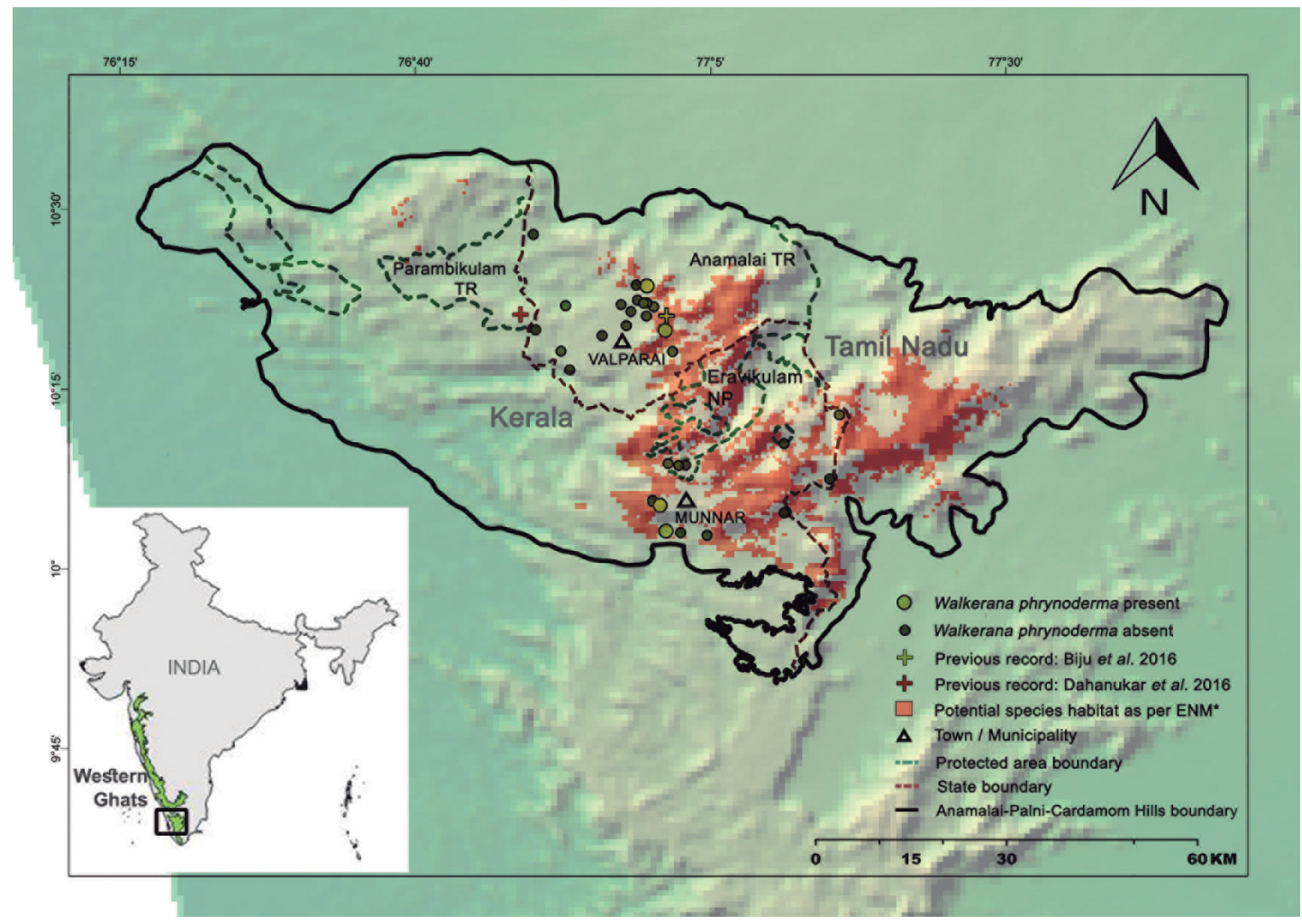

Figure 1. Distribution and potential habitat as per ENM (environment niche model) of the Warty-skinned Leaping Frog, Walkerana phrynoderma in the Anamalai, Palni, and Cardamom hills of the southern Western Ghats, India. 
Table 1. Weather and habitat characteristics of sites occupied by Walkerana phrynoderma including the frog's basic morphology.

\begin{tabular}{|c|c|c|}
\hline & Range & Mean \pm SE \\
\hline Snout-vent length (cm) & $0.9-4.7$ & $2.6 \pm 0.2$ \\
\hline Mass (g) & $0.1-15.0$ & $3.4 \pm 0.7$ \\
\hline Elevation (m a.s.l.) & $1317-1703$ & $1601.7 \pm 13.7$ \\
\hline Air temperature $\left({ }^{\circ} \mathrm{C}\right)$ & $15.4-21.5$ & $18.1 \pm 0.3$ \\
\hline Soil temperature $\left({ }^{\circ} \mathrm{C}\right)$ & $15.9-20.7$ & $18.2 \pm 0.2$ \\
\hline Water temperature $\left({ }^{\circ} \mathrm{C}\right)$ & $16.4-19.4$ & $17.7 \pm 0.2$ \\
\hline Humidity (\%) & $65-100$ & $85.5 \pm 1.6$ \\
\hline Distance from closest water source (m) & $0.18-500.0$ & $40.5 \pm 16.8$ \\
\hline Distance from closest perennial stream (m) & $0.6-500.0$ & $46.7 \pm 16.6$ \\
\hline Bank height $(\mathrm{cm})$ & $0.0-28.0$ & $3.2 \pm 1.6$ \\
\hline & \multicolumn{2}{|c|}{ Percentage $(\%)$} \\
\hline Rainfall & \multicolumn{2}{|c|}{ None $=50$, Little $=23.3$, Moderate $=20$, Heavy $=6.7$} \\
\hline Cloud cover & \multicolumn{2}{|c|}{ Overcast $=100$} \\
\hline Wind & \multicolumn{2}{|c|}{ None $=50$, Little $=43.3$, Moderate $=6.7$} \\
\hline Resting substrate & \multicolumn{2}{|c|}{ Mud $=26.7$, Litter $=60$, Moss $=13.3$} \\
\hline
\end{tabular}

and tested them for nitrate $(\mathrm{mg} / \mathrm{L})$, nitrite $(\mathrm{mg} / \mathrm{L})$, ammonia (mg/L), pH (7.4-8.7), alkalinity (0$5.71 \mathrm{meq} / \mathrm{L})$ and carbonate hardness (0-15.7 $\mathrm{dKH})$ with Salifert ${ }^{\circledR}$ test kits following the manufacturer's guidelines. We recorded prevailing weather conditions (Table 1) and described any apparent habitat threats at each site. Because W. phrynoderma was found at only a few sites, a generalized linear model was used to interpret the influence of the weather and water parameters on our ability to detect the frog.

We constructed an environmental niche model with the Maximum Entropy Species Distribution Modeling software (Version 3.4.1) to identify the other areas in and around the Anamalai Hills where W. phrynoderma might occur. To estimate the geographical distribution of the species, we used the following raster layers: precipitation of driest month; temperature seasonality, and altitude from the WorldClim database (Hijmans et al. 2005); and land cover and maximum green vegetation fraction from the USGS database (Broxton et al. 2014). These layers were re-sampled to the WGS 1984 Transverse Mercator projection at a $1 \mathrm{~km}^{2}$ resolution and snapped to the Anamalai Hills landscape that included the Cardamom and Palni hills. The threshold of occurrence in the model was set to minimum training presence to generate the most restrictive niche that contained all the sample localities. We omitted areas of the resulting distribution that were grasslands, wetlands, croplands, and urban areas where we did not encounter this species, despite intensive surveys.

Data recorded for each of 30 Walkerana phrynoderma include the following: elevation, weather parameters, SVL, mass, activity, habitat type (e.g., forest edge / within forest, forest type and stream), substrate, stream-bank height, distance from nearest perennial stream and 
distance from the water source that was nearest to the individual, which could range from a pool to a perennial stream. Each frog was measured with dial Vernier calipers (RSK, to the nearest $0.02 \mathrm{~mm}$ ), and mass was determined with a mini digital weight balance (B001L9CHP0, to the nearest $0.1 \mathrm{~g})$. Detailed morphological measurements (Appendix I) were taken for 17 adult $W$. phrynoderma as per Gopalan et al. (2012). Individual frogs were classified as adult $(>3$ $\mathrm{cm})$, subadult $(<3 \mathrm{~cm}$ and $>0.1 \mathrm{~g})$ or metamorph $(<0.1 \mathrm{~g})$. A measuring tape (to the nearest 0.1 $\mathrm{cm})$ was used to measure habitat-related distances. We conducted ANOVA and KruskalWallis tests to determine whether frogs of different age classes had varied habitat requirements with respect to elevation, weather, habitat, stream bank height, distance from perennial stream and distance from water source.

\section{Swabbing and Detection of $\mathrm{Bd}$ Infection}

During the period 2013-2015, eight Walkerana phrynoderma (Munnar $=5$, Valparai = 3) and $12 \mathrm{~W}$. leptodactyla (Boulenger, 1882) (Munnar $=6$, Valparai $=6$ ) were skin-swabbed in the field and then immediately released at the point of capture. Our aim was to determine the presence of $B d$ in the focal species, as well as in the widespread and more abundant congener. Frogs were swabbed on the ventral surfaceviz., five swab strokes on both thighs, shank, and hind feet and five strokes on drink patch. Powder-free nitrile gloves were used to handle specimens and new gloves were used with each specimen. The swabs were preserved in $70 \%$ ethanol. We attempted to extract $B d$ DNA from swabs following Goka et al. (2009) with modifications (Dahanukar et al. 2013). Quantitative PCR based on SYBR Green method was carried out using primer pair ITS1-3 Chytr and 5.8S Chytr (Boyle et al. 2004) following the protocol of Dahanukar et al. (2013). Serially diluted DNA extracted from $10^{6} \mathrm{Bd}$ zoospores were used as standards. All samples were run in duplicates.

\section{Habitat Survey}

To understand the role of the habitat type on the occurrence of Walkerana phrynoderma, detailed vegetation and soil analyses were undertaken in February 2015. Four sites were identified with the site-based survey-at two, $W$. phrynoderma was known to occur, and two other sites the species had not been detected. All the sites had similar habitats and were located at about the same elevation (1428-1587 m a.s.l.). Three plots $(5 \times 5-\mathrm{m})$ were opportunistically chosen at each site and data described below were recorded from each plot. We measured the diameter of tree trunks at breast height (DBH); if the $\mathrm{DBH}$ was $15 \mathrm{~cm}$ or greater, the plant was considered to be a tree, or to be a sapling if the DBH was between 5 and $15 \mathrm{~cm}$. Shrubs were classified as woody-stemmed, short plants less than $50 \mathrm{~cm}$ high, and seedlings were green herbaceous stems less than $50 \mathrm{~cm}$ high. We counted the trees in each $5 \times 5$-m plot and the number of saplings, shrubs, and seedlings in a randomly selected $2 \times 2-\mathrm{m}$ subplot within the tree plot. Canopy cover was calculated by viewing it through a graduated glass plate $(100$, $1 \times 1-\mathrm{cm}$ squares) attached to a cardboard cylinder. The number and percent of squares that were completely covered by the canopy were recorded. Soil litter of a $10 \times 10 \mathrm{~cm}$ subplot was weighed to calculate litter density $(\mathrm{g})$ with an electronic scale (Weiheng®, to the nearest 0.01 $\mathrm{kg}$ ). The soil $\mathrm{pH}$ and nutrients, organic carbon (g), total nitrogen (\%), available phosphorus $(\mathrm{kg} /$ ha) and available potassium ( $\mu$ g per sample) were calculated as per Motsara and Roy (2008). The parameter data from the three plots were either averaged (all soil characteristics and canopy cover) or added (all vegetation characteristics except canopy cover) to reflect the characteristics of the entire site. The means of the parameters for the sites where $W$. phrynoderma were present and the sites lacking the species were used for qualitative comparisons because the sample sizes were too small for robust statistical comparisons. 


\section{Time-activity Budget Survey}

We observed adult Walkerana phrynoderma in the rainy season (August-September) in 2014 between 07:00 and 19:30 h to document their behavior, which was recorded as a time-activity budget. This time-period was chosen as per the conditions of our official research permissions and safety concerns due to the presence of large megafauna. The activities of each individual frog (i.e., resting, moving, and feeding) and the duration of each activity were recorded during half-hour periods; we employed the focal animalsampling technique in which three different observers alternate between the half-hour periods (Altmann 1974, Smart et al. 2014). If visual contact was lost, observations were recorded up to the point it was lost. Frogs were not marked for identification and those observed on different days were treated as different individuals. We used red light to observe frogs after 18:00 $\mathrm{h}$ to minimize disturbance (Dayananda and Wickramsinghe 2013). Frog activities were categorized according to the different timeperiods $($ Morning $=07: 00-12: 00 ;$ Afternoon $=$ 12:01-17:00; Evening = 17:01-19:30) and analyzed with a one-way ANOVA to test whether the time period affected activity in $W$. phrynoderma.

\section{Transect Survey}

To estimate the relative abundance and the factors that influence the number of Walkerana phrynoderma found, three 70-m transects, each subdivided into seven 10-m segments were surveyed. Each transect was established in a different habitat within the species range (Appendix II) and were marked across existing routes/pathways to minimize habitat disturbance and comply with the terms of research permission. Each transect segment was actively searched up to a height of $0.3 \mathrm{~m}$ for $5 \mathrm{~min}$; these surveys were repeated seven times from 18:00 19:30 h by two observers from AugustNovember 2014. Each observer searched one side $(2 \mathrm{~m})$ of the transect line and observers switched sides at every $10-\mathrm{m}$ segment. The numbers of individuals of each species/genus encountered were recorded in each segment, and climatological data were recorded at the start and end of each survey.

The total number of amphibians observed, the proportion of each species, and the numbers of Walkerana phrynoderma, W. leptodactyla, Micrixalus sp., and Raorchestes sp. found were compared among transects. The latter taxa were chosen because their higher abundances provided larger sample sizes for analyses; other species were excluded. Transect-level differences were explored with Kruskal-Wallis tests. The relationship between climatological data and total amphibian abundance, as well as the abundance of $W$. phrynoderma were examined by linear regression analyses. The means of the weather data recorded during the beginning and end of the survey were calculated and utilized for this analysis.

\section{Results}

\section{Site-based Survey}

Walkerana phrynoderma occurred at four of 38 sites surveyed (2 each in Tamil Nadu and Kerala, 1321-1649 m a.s.l.; Figure 1). The environmental niche model (training data AUC $=0.990$ ) predicted an area of approximately 940 $\mathrm{km}^{2}$ including the Eravikulam National Park and Kodaikanal Wildlife Sanctuary (Palni Hills). Of the factors that could affect the presence / absence of $W$. phrynoderma, only air temperature and the amount of ammonia in the stream water differed significantly (Table 2). Air temperature was lower at sites occupied by $W$. phrynoderma $\left(17.8 \pm 0.9^{\circ} \mathrm{C}\right.$ vs. $\left.19.7 \pm 0.4^{\circ} \mathrm{C}\right)$. Ammonia was higher at sites occupied by $W$. phrynoderma $(0.25 \pm 0 \mathrm{mg} / \mathrm{L}$ vs. $0.09 \pm 0.1 \mathrm{mg} / \mathrm{L})$. The greatest threats in all survey locations are the potential for pesticide runoff from surrounding tea, coffee, and cardamom plantations ( $N=27$ locations), degraded habitat $(N=9)$, roads $(N=7)$, firewood 
collection $(N=3)$, livestock grazing $(N=3)$, and garbage and solid waste $(N=3)$. The four locations where $W$. phrynoderma occurs are threatened by potential pesticide runoff $(N=4)$, firewood collection $(N=2)$, livestock grazing $(N$ $=1)$, degraded habitat $(N=1)$, roads $(N=1)$, and garbage and solid waste $(N=1)$.

Walkerana phrynoderma are small frogs with a maximum SVL of $4.7 \mathrm{~cm}$ (Table 1). Although predominantly brownish in color, some adults are reddish. The tympanum usually is $75 \%$ the eye diameter (Appendix I) and its distinctiveness varies. The extent of the dorsal tuberculation varies, with larger individuals having less coverage. The dorsum has a characteristic $\mathrm{W}$-shaped ridge composed of large tubercles, which is distinct in subadult and adult frogs. The venter is predominantly black with white speckles; the patterns vary individually. The toes lack webbing. The sex of the individuals cannot be determined by external examination. Walkerana phrynoderma were found only in tropical montane evergreen forests; four metamorphs were encountered near a stream at the edge of an evergreen forest and montane grassland during the monsoon in August 2013. Walkerana phrynoderma was restricted to a high montane altitudinal zone and usually found associated with soil litter (Table 1). They were found in the vicinity of water sources $(40.5 \pm$ $16.8 \mathrm{~m}$ ) or away from them; the frogs were not seen in water (Table 1). Most $(70 \%)$ frogs were encountered at forest edges, rather than deep within the forest $(30 \%)$. All were found resting on the substrate and were not active during the day.

Different life stages (adults $=11$, subadults $=$ 11 , metamorphs $=8$ ) of $W$. phrynoderma are found on different substrates (Kruskal-Wallis Test, $\chi^{2}=7.5, d f=2, p=0.02$ ). Metamorphs usually were associated with moss $(50 \%)$ and litter $(37.5 \%)$, subadults with bare soil $(54.5 \%)$ and litter (45.5\%), and adults with litter (81.8\%). The distance of the frogs from the closest perennial stream also varies with life stage (Kruskal Wallis Test, $\chi^{2}=6.2, d f=2, p=0.04$ ). Metamorphs were found closer to streams (17.3 $\pm 11.9 \mathrm{~m})$ than subadults $(37.6 \pm 8.3 \mathrm{~m})$, and adults were found farthest from streams $(77.4 \pm$ $43.2 \mathrm{~m}$ ).

Table 2. Generalized linear models to interpret the effect of weather and water-quality parameters on presence / absence of Walkerana phrynoderma.

\begin{tabular}{lcccc}
\hline & $\boldsymbol{B}$ & Std Error & Wald Chi-square & $\boldsymbol{p}$ \\
\hline Intercept & 5.58 & 10.31 & 0.29 & 0.59 \\
Elevation & $>0.01$ & $>0.01$ & 1.60 & 0.21 \\
Air temperature & 0.08 & 0.04 & 4.28 & 0.04 \\
Soil temperature & -0.03 & 0.03 & 0.94 & 0.33 \\
Humidity & -0.01 & 0.01 & 0.24 & 0.62 \\
pH & -0.63 & 1.40 & 0.20 & 0.65 \\
Ammonia & -1.45 & 0.46 & 9.75 & $>0.01$ \\
Nitrate & 0.01 & 0.01 & 0.29 & 0.59 \\
Alkalinity & 1.63 & 1.23 & 1.76 & 0.19 \\
Carbonate hardness & -0.57 & 0.43 & 1.79 & 0.18 \\
\hline
\end{tabular}




\section{Habitat Survey}

Walkerana phrynoderma was found on wellshaded forest floors, which is inferred from the canopy cover and the number of saplings and shrubs. Even though there were fewer trees at sites with $W$. phrynoderma, the canopy cover resembled that of sites lacking this species (Table 3). Consequently, at the sites where $W$. phrynoderma occurred, there were more saplings and fewer seedlings (Table 3), and the soil contained less nitrogen, phosphorus, and potassium.

\section{Time-activity Budget Survey}

In a period of 6 days, a total of $11.85 \mathrm{~h}$ was spent observing the activity of Walkerana phrynoderma. Individuals usually rested either in, or on, leaf litter (11.84 h), and were observed moving $0.01 \mathrm{~h}$. Vocalizations were not heard, and no significant differences were found between the activities undertaken and the different time periods from 07:00-19:30 h.

\section{Transect Survey}

Anuran encounter rates differed among the three transects (Kruskal Wallis test, $\chi^{2}=6.9, d f$ $=2, p=0.03$ ); the most frogs were found in the forest edge transect inside PA and the fewest in the forest transect (Figure 2). Walkerana leptodactyla was the most common species in all transects, followed by Raorchestes sp., $W$. phrynoderma, and Micrixalus sp. (Figure 2). The total numbers of $W$. phrynoderma (KruskalWallis test, $\left.\chi^{2}=12.2, d f=2, p<0.01\right), W$. leptodactyla (Kruskal Wallis test, $\chi^{2}=10.9, d f=$ $2, p<0.01$ ), and Micrixalus sp. (Kruskal-Wallis test, $\left.\chi^{2}=11.7, d f=2, p<0.01\right)$ differed in the three transects. The fewest $W$. phrynoderma were found in the forest interior transect in contrast to the other transects (Figure 2). The most $W$. leptodactyla were found in the forest edge transect outside PA, and the least in the forest interior transect. Most Micrixalus sp. were found in the forest edge transect inside PA and the fewest in the forest edge outside PA (Figure 2).

Table 3. Vegetation and soil characteristics of sites with and without Walkerana phrynoderma.

\begin{tabular}{lcc}
\hline & Sites with $\boldsymbol{W}$. phrynoderma $(\mathbf{N}=\mathbf{2})$ & Sites without $\boldsymbol{W} \cdot \mathbf{p h r y n o d e r m a ~}(\mathbf{N}=\mathbf{2})$ \\
\hline Canopy cover $(\%)$ & $93 \pm 4$ & $93 \pm 1$ \\
Tree number & $5.5 \pm 1.5$ & $12.0 \pm 3$ \\
Sapling number & $44 \pm 19$ & $31.5 \pm 9.5$ \\
Shrub number & $28 \pm 10$ & $20.5 \pm 11.5$ \\
Seedling number & $76 \pm 28 \pm 50$ \\
Litter weight $(\mathrm{g})$ & $0.18 \pm 0.02$ & $0.25 \pm 0.05$ \\
Soil pH & $4.6 \pm 0.01$ & $4.7 \pm 0.44$ \\
Organic carbon $(\mathrm{g})$ & $0.51 \pm 0.28$ & $0.47 \pm 0.05$ \\
Total nitrogen $(\%)$ & $38.36 \pm 0.04$ & $54.97 \pm 2.09$ \\
Available phosphorus $(\mathrm{kg} / \mathrm{ha})$ & $0.16 \pm 0.02$ & $0.24 \pm 0.04$ \\
Available potassium $(\mu \mathrm{g}$ per sample) & $35.75 \pm 1.72$ & $40.62 \pm 5.12$ \\
\hline
\end{tabular}


Weather conditions did not affect the total number of W. phrynoderma encountered, but it did influence the total number of anurans found (Table 4). Substrate temperature is inversely correlated with the total number of frogs found.

\section{Bd Infection Detection}

All 20 samples (8 Walkerana phrynoderma and $12 \mathrm{~W}$. leptodactyla) tested negative for $B d$ with less than one zoospore equivalent for both the runs of quantitative PCR.

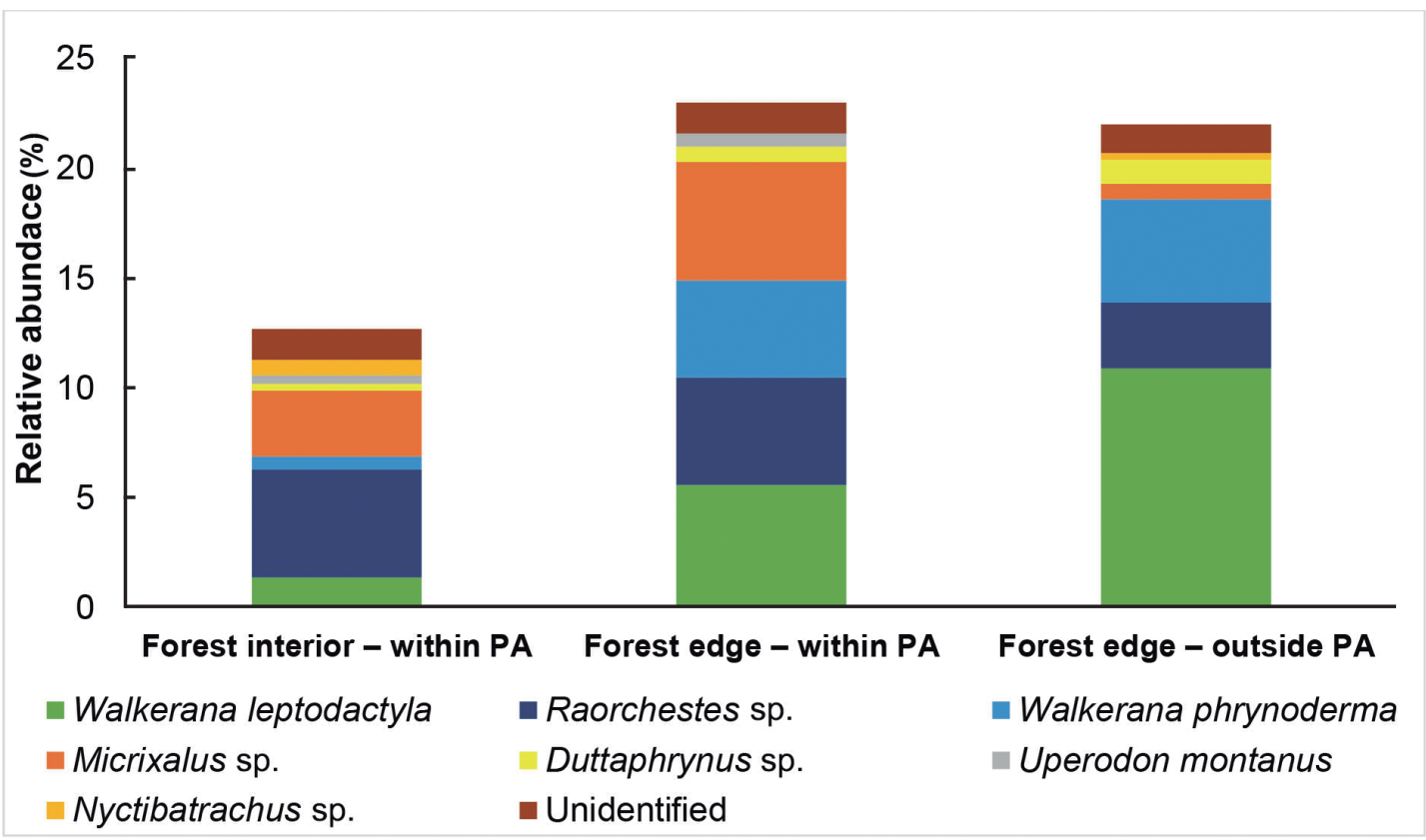

Figure 2. Relative abundance of anurans found along the three transects in the Anamalai Hills; "unidentified" refers to frogs that moved away before they could be identified.

Table 4. Linear regression analysis describing the effect of weather parameters on the total number of anurans encountered during the transect survey.

\begin{tabular}{|c|c|c|c|c|c|}
\hline & B & Std Error & Beta & $T$ & $p$ \\
\hline Constant & -75.2 & 70.8 & & -1.1 & 0.31 \\
\hline Air temperature & -4.3 & 3.4 & -0.36 & -1.2 & 0.24 \\
\hline Soil temperature & 8.2 & 3.1 & 0.80 & 2.7 & 0.02 \\
\hline Humidity & $>0.1$ & 0.2 & -0.01 & -0.1 & 0.97 \\
\hline Rainfall & -3.5 & 3.0 & -0.35 & -1.2 & 0.27 \\
\hline Wind & 0.7 & 3.4 & 0.05 & 0.2 & 0.85 \\
\hline Cloud cover & 4.7 & 4.5 & 0.30 & 1.0 & 0.32 \\
\hline
\end{tabular}




\section{Discussion}

Distribution, Habitat, and Activity of Walkerana phrynoderma

The range of Walkerana phrynoderma extends outside the PA network to Munnar in the Anamalai Hills of southern Western Ghats-30.5 $\mathrm{km}$ south of its recorded locality in the Anamalai Tiger Reserve. The species will still be assessed as Critically Endangered (B1ab(i,ii,iii) + $2 \mathrm{ab}(\mathrm{i}, \mathrm{ii}, \mathrm{iii}))$ as per the IUCN Redlist because its distribution is restricted to an area estimated to be $26.3 \mathrm{~km}^{2}$ and an area of occupancy of $5 \mathrm{~km}^{2}$ that is severely fragmented and predicted to diminish in size as a result of ongoing anthropogenic activities. As per this study, the species is known from one severely fragmented locality, where the area, extent, and quality of its habitat is expected to decline owing to the potential runoff of chemical effluents from tea plantations and development of large-scale tourism infrastructure. The altitudinal range of W. phrynoderma is much more restricted than previously thought; we only found the species at elevations between 1300 and $1700 \mathrm{~m}$ a.s.l. Other field studies have recorded the species at $928 \mathrm{~m}$ (Parambikulam; Dahanukar et al. 2016) and $1750 \mathrm{~m}$ a.s.l. (Valparai, the same field site as ours; Garg and Biju 2016). The locality reported by Dahanukar et al. (2016) should be verified because the individual depicted in the image appears to be under severe stress and its habitat seems to be unnatural and different from the type locality. Moreover, our study involved a meticulous survey across 38 different locations from elevations of 600-2100 m a.s.l. It included the protected area adjacent to Parambikulam (Topslip, Anamalai Tiger Reserve), the location where $W$. phrynoderma was thought to occur previously as reported by Biju et al. (2014) but we did not find the species at $900 \mathrm{~m}$ a.s.l. Also, Garg and Biju (2016) did not encounter it at 955 $\mathrm{m}$ a.s.l. in Parambikulam. Our results suggest that $W$. phrynoderma occupies a highly restricted range in the Anamalai Hills and the adjoining
Cardamom Hills of the Western Ghats. The geographical distribution model must be interpreted with caution given the limited sample size. However, it does provide information on other regions where populations of $W$. phrynoderma could occur and we suggest that these areas should be surveyed as a priority.

In general, frogs of the genera Indirana and Walkerana are terrestrial and live on the forest floor amidst leaf litter, short grass, and wet rocks close to streams (Nair et al. 2012). However, adult $W$. phrynoderma are less dependent on proximity of streams or water as is I. brachytarsus (Daniels 2005), at least during the time of year that we undertook our surveys. The difference in habitat preference between metamorphs, subadults, and adults of $W$. phrynoderma might reflect ontogenic shifts in foraging habitat preferences, varying mobility in different habitats, different structural support required from their habitat, or natal site fidelity (Beard et al. 2003, Haggarty 2006, Valdez et al. 2016). The expected breeding sites of Walkerana / Indirana (wet rock surfaces) were searched opportunistically in the habitat of $W$. phrynoderma, but tadpoles of the species were not observed. The reproductive biology and vocalization of this species are unknown. Although they may have the same reproductive mode as ranixalid frogs, given the association of metamorphs and streams, this cannot be confirmed and warrants further study. Walkerana phrynoderma is a nocturnal species even though it can be found by day (Garg and Biju 2016) when it is not active. When these frogs are not moving, they are well camouflaged and difficult to detect on the terrestrial substrate.

Walkerana phrynoderma was found on wellshaded forest floors with the same amount of canopy cover as the sites lacking the species. The difference is that the habitats occupied by $W$. phrynoderma had fewer, but larger trees with wider crowns; this, combined with higher elevations may result in lower air temperatures that are more favorable for the species. The areas also have nutrient-poor soils, and higher ammonia content in the water. 


\section{Relative Abundance}

Walkerana phrynoderma seems to be restricted to a few discontinuous fragments of tropical evergreen forest, where it apparently is not the most common frog in the anuran assemblage in the habitat. Globally, there have been numerous studies investigating the microclimatic variation between forest edges and interiors (Chen et al. 1993, Ewers and Banks-Leite 2013, Baltzer et al. 2014). Different habitats and degree of disturbance seem to affect the overall relative abundance of amphibians because the forest edges support a higher relative abundance of certain species in this case and $W$. phrynoderma specifically. The apparent edge effect should be interpreted cautiously as the denser vegetation in the forest interior could have an impact on detection probability. Moreover, these results could be seasonally biased because the surveys were undertaken during monsoon seasons, and the abundances of amphibians in the forest edges and interior are influenced by such seasonality (Schlaepfer and Gavin 2001).

\section{Threats Faced by Walkerana phrynoderma}

A major threat to this species is habitat loss resulting from subsistence wood collection by local communities (Biju et al. 2004a). This, along with habitat fragmentation, are obvious and important threats, and this study emphasizes another-viz., the close proximity of Walkerana phrynoderma to tea plantations, where anurans may be exposed to pesticide runoff. Chemical pollution is a major threat to amphibians and there is evidence of the susceptibility of amphibians to the toxic effects of nitrogenous compounds (Beebee and Griffiths 2005, EgeaSerrano et al. 2009). At organic coffee plantations in the Western Ghats, the relative abundance of amphibians was found to be higher than at coffee plantations that used fertilizers and pesticides (Rathod and Rathod 2013). Pesticide runoff is associated with population declines (Davidson and Knapp 2007), deformities (Taylor et al.
2005, Gurushankara et al. 2007a, b), and reduced immune response, each of which renders anurans more susceptible to diseases (Carey et al. 1999, Christin et al. 2004). Bd was detected in the Western Ghats relatively recently, but we do not know whether infection leads to lethal chytridiomycosis in amphibians in this region (Nair et al. 2011, Dahanukar et al. 2013, Molur et al. 2015). $B d$ has been found to infect species of the genus Indirana (Nair et al. 2011, Dahanukar et al. 2013, Molur et al. 2015), but it has not been found in W. phrynoderma; thus, chytridiomycosis may not threaten the species currently. However, our sample size was limited. Further, the range of $W$. phrynoderma is coincident with an area where there is a high probability of chytrid presence owing to cool ambient temperatures (Molur et al. 2015). Thus, long-term population monitoring and pathogen surveillance should be undertaken so that any population decline is detected early and suitable conservation interventions can be implemented in time.

\section{Conservation Measures}

The actual effect of pesticides, livestock grazing, and firewood collection by local communities on the population of Walkerana phrynoderma must be determined to formulate appropriate conservation measures. Existing tourism-induced disturbances (especially waste disposal) should be reviewed by the Forest Department within and outside protected areas (Reserve Forests) with the aim of reducing the impact of tourism on the habitat of a species with highly specific environmental requirements. The development of new tourism infrastructure (trekking routes, buildings, and roads) within Forest Department-owned land should be avoided if possible. Once calculated, organizations should strictly adhere to the tourist-carrying capacity of sites, given that this Critically Endangered species has a limited distribution. The Forest Departmentowned land outside the protected areas (Reserve Forests) could be declared as eco-sensitive to 
prevent management-induced, land-use changes that may have a detrimental effect on populations of $W$. phrynoderma. This is especially critical given that the abundance of $W$. phrynoderma outside the protected area is similar as that of protected areas; thus, these unprotected sites should be monitored to ensure that crucial tracts of habitat are protected in the range of $W$. phrynoderma. Last, the Forest Department should ensure that its front-line staff is able to identify and monitor at least key amphibian species (Kanagavel et al. 2017b). Official, annual amphibian-monitoring programs such as those that exist for megafauna (Kumara et al. 2012) should be initiated to provide data to track the status of threatened anurans and undertake appropriate conservation interventions when necessary.

\section{Acknowledgments}

The authors thank Carly Waterman, Cath Lawson, Craig Turner, Olivia Couchman, and Rajeev Raghavan for their support in designing and sustaining the study. Monica Harpalani, Nithula Nirmal, and Mohammed Ismail participated in the field surveys and Nisha Owen and Raj Amin helped analyze data. The authors also thank the two reviewers and the Editors for their detailed suggestions which have improved the final manuscript. Financial support was provided by the ZSL EDGE Fellowship 2012, Rufford Small Grant for Nature Conservation (17771-2), Idea Wild, and Conservation Leadership Programme, Future Conservationist Award 2015 (03234915) to AK and the Mohammed Bin Zayed Species Conservation Fund (12253920). Official research permission was granted by the Tamil Nadu and Kerala Forest Department (WL5/28696/2012, WL5(A)/16458/2014 and WL 10-15417/2014). ND thanks the Director and Dean of Biological Sciences, Indian Institute of Science Education and Research, Pune, for providing infrastructural facilities and to DSTINSPIRE Faculty Fellowship (IFA12-LSBM-21) for financial support for chytrid work.

\section{References}

Altmann, J. 1974. Observational study of behavior: sampling methods. Behavior 49: 227-267.

AZE. 2013. Alliance for zero extinction. Electronic Database accessible at http://www.zeroextinction.org/ American Bird Conservancy, Washington DC, USA. Captured on 04 March 2017.

Baillie, J. E. M., J. Griffiths, S. T. Turvey, J. Loh, and B. Collen. 2010. Evolution Lost: Status and Trends of the World's Vertebrates. London. Zoological Society of London. 72 pp.

Baltzer, J. L., T. Veness, L. E. Chasmer, A. E. Sniderhan, and W. L. Quinton. 2014. Forests on thawing permafrost: fragmentation, edge effects, and net forest loss. Global Change Biology 20: 824-834.

Beard, K. H., S. McCullough, and A. K. Eschtruth. 2003. Quantitative assessment of habitat preferences for the Puerto Rican terrestrial frog, Eleutherodactylus coqui. Journal of Herpetology 37: 10-17.

Beebee, T. J. C. and R. A. Griffiths. 2005. The amphibians decline crisis: a watershed for conservation biology? Biological Conservation 125: 271-285.

Biju, S. D. and F. Bossuyt. 2009. Systematics and phylogeny of Philautus Gistel, 1848 (Anura, Rhacophoridae) in the Western Ghats of India, with descriptions of 12 new species. Zoological Journal of the Linnean Society 155: 374-444.

Biju, S. D. and S. Dutta. 2004. Indirana leptodactyla. The IUCN Red List of Threatened Species. Version 2014.3 (30 April 2004). Electronic Database accessible at http: www.iucnredlist.org/ IUCN Global Species Red List Unit, Cambridge, UK. Captured on 01 December 2017.

Biju, S. D., S. P. Vijayakumar, and S. Dutta. 2004a. Indirana phrynoderma. The IUCN Red List of Threatened Species. Version 2014.3 (30 April 2004). Electronic Database accessible at http: www.iucnredlist.org/ IUCN Global Species Red List Unit, Cambridge, UK. Captured on 01 December 2017.

Biju, S. D., S. Dutta, R. Inger, and M. S. Ravichandran. 2004b. Indirana diplosticta. The IUCN Red List of Threatened Species. Version 2014.3 (30 April 2004). Electronic Database accessible at http: www.iucnredlist. org/ IUCN Global Species Red List Unit, Cambridge, UK. Captured on 07 July 2017.

Biju, S. D., Y. Shouche, A. Dubois, S. K. Dutta, and F. Bossuyt. 2010. A ground-dwelling rhacophorid frog 
from the highest mountain peak of the Western Ghats of India. Current Science 98: 1119-1125.

Biju, S. D., I. Van Bocxlaer, S. Mahony, K. P. Dinesh, C. Radhakrishnan, A. Zachariah, V. B. Giri, and F. Bossuyt. 2011. A taxonomic review of the night frog genus Nyctibatrachus Boulenger, 1882 in the Western Ghats, India (Anura: Nyctibatrachidae) with description of twelve new species. Zootaxa 3029: 1-96.

Biju, S. D., S. Garg, K. V. Gururaja, Y. Shouche, and S. A. Walujkar. 2014. DNA barcoding reveals unprecedented diversity in dancing frogs of India (Micrixalidae, Micrixalus): a taxonomic revision with description of 14 new species. Ceylon Journal of Science (Biological Sciences) 43: 37-123.

Boulenger, G. A. 1890. The Fauna of British India, Including Ceylon and Burma: Reptilia and Batrachia. London. Taylor \& Francis. 541 pp.

Boyle, D. G., D. B. Boyle, V. Olsen, J. A. Morgan, and A. D. Hyatt. 2004. Rapid quantitative detection of chytridiomycosis (Batrachochytrium dendrobatidis) in amphibian samples using real-time Taqman PCR assay. Diseases of Aquatic Organisms 60: 141-148.

Broxton, P. D., X. Zeng, D. Sulla-Menashe, and P. A. Troch. 2014. A global land cover climatology using MODIS data. Journal of Applied Meteorology and Climatology 53: 1593-1605.

Carey, C., N. Cohen, and L. Rollins-Smith. 1999. Amphibian declines: an immunological perspective. Developmental and Comparative Immunology 23: 459-472.

Chen, J., J. F. Franklin, and T. A. Spies. 1993. Contrasting microclimates among clearcut, edge, and interior of oldgrowth Douglas-fir forest. Agricultural and Forest Meteorology 63: 219-237.

Christin, M. S., L. Ménard, A. D. Gendron, S. Ruby, D. Cyr, D. J. Marcogliese, L. Rollins-Smith, and M. Fournier. 2004. Effects of agricultural pesticides on the immune system of Xenopus laevis and Rana pipiens. Aquatic Toxicology 67: 33-43.

Dahanukar, N., K. Krutha, M. S. Paingankar, A. D. Padhye, N. Modak, and S. Molur. 2013. Endemic Asian chytrid strain infection in threatened and endemic anurans of the Northern Western Ghats, India. PLoS ONE 8: e77528.

Dahanukar, N., N. Modak, K. Krutha, P. O. Nameer, A. D. Padhye, and S. Molur. 2016. Leaping frogs (Anura: Ranixalidae) of the Western Ghats of India: an integrated taxonomic review. Journal of Threatened Taxa 8: 9221-9288.

Daniels, R. J. R. 2005. Amphibians of Peninsular India. Hyderabad. Universities Press. 268 pp.
Davidson, C. and R. A. Knapp. 2007. Multiple stressors and amphibian declines: dual impacts of pesticides and fish on yellow-legged frogs. Ecological Applications 17: $587-597$.

Dayananda, S. K. and D. D. Wickramsinghe. 2013. Activity budget and perch characteristics of Pseudophilautus popularis (Manamendra-Arachchi \& Pethiyagoda, 2005) (Amphibia: Rhacophoridae) during the breeding season. Taprobanica 6: 7-12.

Egea-Serrano, A., M. Tejedo, and M. Torralva. 2009. Populational divergence in the impact of three nitrogenous compounds and their combination on larvae of the frog Pelophylax perezi (Seoane, 1885). Chemosphere 76: 869-877.

Ewers, R. M. and C. Banks-Leite. 2013. Fragmentation impairs the microclimate buffering effect of tropical forests. PLOS ONE 8: e58093.

Frost, D. R. 2017. Amphibian species of the world: an online reference. Version 6.0 (1 December 2017). Electronic Database accessible at http://research.amnh. org/herpetology/amphibia/index.html/ American Museum of Natural History, New York, USA. Captured on 1 December 2017.

Gaitonde, N. and V. Giri. 2014. Primitive breeding in an ancient Indian frog genus Indirana. Current Science 107: 109-112.

Garg, S. and S. D. Biju. 2016. Molecular and morphological study of leaping frogs (Anura, Ranixalidae) with description of two new species. PLOS ONE 11: e0166326.

Goka, K., J. U. N. Yokoyama, Y. Une, T. Kuroki, K. Suzuki, M. Nakahara, A. Kobayashi, S. Inaba, T. Mizutani, and A. D. Hyatt. 2009. Amphibian chytridiomycosis in Japan: distribution, haplotypes and possible route of entry into Japan. Molecular Ecology 18: 4757-4774.

Gopalan, S. V., A. Nair, K. S. Kumar, J. Merilä, and S. George. 2012. Morphology of Indirana semipalmata (Boulenger, 1882) (Amphibia; Anura) adults and tadpoles from the Western Ghats, India. Herpetology Notes 5: 263-273.

Gurushankara, H. P., S. V. Krishnamurthy, and V. Vasudev. 2007a. Morphological abnormalities in natural populations of common frogs inhabiting agroecosystems of central Western Ghats. Applied Herpetology 4: 3945.

Gurushankara, H. P., D. Meenakumari, S. V. Krishnamurthy, and V. Vasudev. 2007b. Impact of malathion stress on lipid metabolism in Limnonectus limnocharis. Pesticide Biochemistry and Physiology 88: 50-56. 
Haggarty, M. 2006. Habitat differentiation and resource use among different age classes of post metamorphic Rana boylii on Red Bank creek, Tehama county, California. Unpuplished Ph.D. Dissertation. Humboldt State University, USA.

Hijmans, R. J., S. E. Cameron, J. L. Parra, P. G. Jones, and A. Jarvis. 2005. Very high resolution interpolated climate surfaces for global land areas. International Journal of Climatology 25: 1965-1978.

Hoffmann, M., C. Hilton-Taylor, A. Angulo, M. Böhm, T. M. Brooks, S. H. M. Butchart, K. E. Carpenter, J. Chanson, B. Collen, N. A. Cox, W. R. T. Darwall, N. K. Dulvy, L. R. Harrison, V. Katariya, C. M. Pollock, S. Quader, N. I. Richman, A. S. L. Rodrigues, M.F. Tognelli, J. C. Vié, et al. 2010. The impact and shortfall of conservation on the status of the world's vertebrates. Science 330: 1503-1509.

Isaac, N. J. B., D. W. Redding, H. M. Meredith, and K. Safi. 2012. Phylogenetically-informed priorities for amphibian conservation. PLOS ONE 7: e43912.

IUCN 2017. IUCN Red List of Threatened Species. Version 2017.1. Electronic Database accessible at www. iucnredlist.org/ IUCN Global Species Red List Unit, Cambridge, UK. Captured on 24 March 2017.

Kanagavel, A., L. M. Eluvathingal, S. Parvathy, R. Kotharambath, and S. Das. 2017a. Potential flagship species for improving support and garnering attention towards amphibian conservation in the Western Ghats, India. Pp. 271-292 in A. Das (ed.), Diversity \& Ecology of Amphibians of India, ENVIS Bulletin: Wildlife \& Protected Areas, Volume 19. Dehradun. Wildlife Institute of India.

Kanagavel, A., S. Parvathy, and N. Divakar. 2017b. Education workshops improve the ability of forest departments to identify amphibians in Western Ghats, India. Conservation Evidence 14: 21 .

Kumara, H. N., S. Rathnakumar, M. A. Kumar, and M. Singh. 2012. Estimating Asian elephant, Elephas maximus, density through distance sampling in the tropical forests of Biligiri Rangaswamy temple tiger reserve, India. Tropical Conservation Science 5: 163 172.

Kumaraguru, A., R. Saravanamuthu, K. Brinda, and S. Asokan. 2011. Prey preference of large carnivores in Anamalai Tiger Reserve, India. European Journal of Wildlife Research 57: 627-637.

Molur, S., K. Krutha, M. S. Paingankar, and N. Dahanukar. 2015. Asian strain of Batrachochytrium dendrobatidis is widespread in the Western Ghats, India. Diseases of Aquatic Organisms 112: 251-255.
Motsara, M. R. and R. N. Roy. 2008. Guide to Laboratory Establishment for Plant Nutrient Analysis. Rome. Food and Agriculture Organization of the United Nations. 204 pp.

Myers, N., R. A. Mittermeier, C. G. Mittermeier, G. A. B. da Fonseca, and J. Kent. 2000. Biodiversity hotspots for conservation priorities. Nature 403: 853-858.

Nair, A., O. Daniel, S. V. Gopalan, S. George, K. S. Kumar, J. Merilä, and A. Teacher. 2011. Infectious disease screening of Indirana frogs from the Western Ghats biodiversity hotspot. Herpetological Review 42: 554 557.

Nair, A., S. V. Gopalan, S. George, K. S. Kumar, A. G. F. Teacher, and J. Merila. 2012. Endemic Indirana frogs of the Western Ghats biodiversity hotspot. Annales Zoologici Fennici 49: 257-286.

Raman, T. R. S. and D. Mudappa. 2003. Bridging the gap: sharing responsibility for ecological restoration and wildlife conservation on private lands in the Western Ghats. Social Change 33: 129-141.

Rameshan, M., A. Roy, and E. V. Ramasamy. 2014. Identification of potential elephant corridor between Anamalai landscape and Periyar Tiger Reserve, southern Western Ghats: a geospatial approach. International Journal of Geoinformatics 10: 41-52.

Rathod, S. and P. Rathod. 2013. Amphibian communities in three different coffee plantation regimes in the Western Ghats, India. Journal of Threatened Taxa 5: 44044413.

Roelants, K., J. Jiang, and F. Bossuyt. 2004. Endemic ranid (Amphibia: Anura) genera in southern mountain ranges of the Indian subcontinent represent ancient frog lineages: evidence from molecular data. Molecular Phylogenetics and Evolution 31: 730-740.

Schlaepfer, M. A. and T. A. Gavin. 2001. Edge effects on lizards and frogs in tropical forest fragments. Conservation Biology 15: 1079-1090.

Skerratt, L. F., L. Berger, R. Speare, S. Cashins, K. R. McDonald, A. D. Phillott, H. B. Hines, and N. Kenyon. 2007. Spread of chytridiomycosis has caused the rapid global decline and extinction of frogs. Eco Health 4: $125-134$.

Smart, U., V. Deepak, and K. Vasudevan. 2014. Preliminary ethogram and in situ time-activity budget of the enigmatic cane turtle (Vijayachelys silvatica) from the Western Ghats, south India. Herpetological Conservation and Biology 9: 116-122.

Sodhi, N. S., D. Bickford, A. C. Diesmos, T. M. Lee, L. P. Koh, B. W. Brook, C. H. Sekercioglu, and C. J. 
Bradshaw. 2008. Measuring the meltdown: drivers of global amphibian extinction and decline. PLOS ONE 3: e1636.

Sridhar, H., S. T. S. Raman, and D. Mudappa. 2008. Mammal persistence and abundance in tropical rainforest remnants in the southern Western Ghats, India. Current Science 94: $748-757$.

Stuart, S. N., J. S. Chanson, N. A. Cox, B. E. Young, A. S. Rodrigues, D. L. Fischman, and R. W. Waller. 2004. Status and trends of amphibian declines and extinctions worldwide. Science 306: 1783-1786.

Tapley, B. T., C. B. Purushotham, and S. Girgin. 2011. Indirana semipalmata (brown leaping frog) reproduction. Herpetological Review 42: 87-88.
Taylor, B., D. Skelly, L. K. Demarchis, M. D. Slade, D. Galusha, and P. M. Rabinowitz. 2005. Proximity to pollution sources and risk of amphibian limb malformation. Environmental Health Perspectives 113: $1497-1501$.

Valdez, J., K. Klop-Toker, M. P. Stockwell, S. Clulow, J. Clulow, and M. J. Mahony. 2016. Microhabitat selection varies by sex and age class in the endangered green and golden bell frog Litoria aurea. Australian Zoologist 38: $223-234$.

Editors: Tim Halliday and Jaime Bertoluci 
Appendix I. Morphometric data for adult Walkerana phrynoderma (10 = Valparai, $7=$ Munnar $)$ as per Gopalan et al. (2012) compared with data reported in the literature.

\begin{tabular}{|c|c|c|c|c|}
\hline & \multicolumn{2}{|c|}{ Current study $(N=17)$} & \multirow{2}{*}{$\begin{array}{c}\text { Garg and Biju } 2016 \\
(N=1)\end{array}$} & \multirow{2}{*}{$\begin{array}{l}\text { Dahanukar et al. } 2016 \\
\text { Mean } \pm \mathrm{SE}(\mathrm{mm}, N=3)\end{array}$} \\
\hline & Range (mm) & Mean \pm SE $(\mathrm{mm})$ & & \\
\hline Snout-vent length & $23.7-46.6$ & $32.7 \pm 1.4$ & 33.9 & $24.8 \pm 6.4$ \\
\hline Head length & $9.8-18.4$ & $12.9 \pm 0.6$ & 13.1 & $9.9 \pm 2.5$ \\
\hline Head width & $10.7-19.6$ & $14.0 \pm 0.6$ & 13.7 & $9.6 \pm 2.4$ \\
\hline Maximum eye diameter & $3.1-5.5$ & $4.0 \pm 0.2$ & 4.0 & $2.9 \pm 0.8$ \\
\hline Eyelid width & $2.7-4.3$ & $3.2 \pm 0.1$ & 3.3 & $2.3 \pm 0.5$ \\
\hline Interorbital distance & $2.3-4.8$ & $3.2 \pm 0.2$ & 2.9 & $2.6 \pm 0.5$ \\
\hline Tympanum diameter & $1.9-3.8$ & $2.8 \pm 0.1$ & 2.1 & $1.4 \pm 0.4$ \\
\hline Eye-snout distance & $4.1-8.4$ & $5.7 \pm 0.3$ & - & - \\
\hline Eye-naris distance & $1.9-4.2$ & $2.9 \pm 0.2$ & - & $2.2 \pm 0.5$ \\
\hline Naris-snout distance & $2.2-4.4$ & $3.0 \pm 0.2$ & - & $2.3 \pm 0.5$ \\
\hline Internasal distance & $3.0-6.3$ & $4.3 \pm 0.2$ & - & $3.2 \pm 0.8$ \\
\hline Upper arm length & $4.3-11.1$ & $6.6 \pm 0.4$ & - & $5.5 \pm 1.4$ \\
\hline Forearm length & $5.6-10.2$ & $7.3 \pm 0.4$ & 6.2 & $5.2 \pm 1.5$ \\
\hline Hand length & $5.2-13.0$ & $8.2 \pm 0.4$ & 8.3 & $5.9 \pm 1.5$ \\
\hline Thigh length & $13.8-28.1$ & $19.1 \pm 0.9$ & 18.4 & $13.4 \pm 3.2$ \\
\hline Shank length & $15.0-31.4$ & $20.7 \pm 1.0$ & 20.1 & $15.0 \pm 4.2$ \\
\hline Tarsus length & $8.4-15.4$ & $10.8 \pm 0.7$ & - & $7.1 \pm 2.1$ \\
\hline Total foot length & $16.2-28.1$ & $18.8 \pm 1.1$ & 17.8 & $17.5 \pm 5.3$ \\
\hline
\end{tabular}

Appendix II. Description of the habitat at transects setup in Walkerana phrynoderma's range.

\begin{tabular}{cccc}
\hline & Habitat & Elevation (m a.s.l.) & Site status \\
\hline 1 & $\begin{array}{c}\text { Partially paved road that forms an edge between two evergreen forest } \\
\text { patches of primary vegetation. }\end{array}$ & 1597 & Within protected area \\
2 & Evergreen forest interior that lacks a paved or well-defined path. & 1551 & Within protected area \\
& $\begin{array}{l}\text { Boundary path between a Reserve Forest and privately owned land. } \\
\text { The area is abandoned and no longer cultivated. The upper canopy is } \\
\text { primary vegetation, whereas the lower is secondary. }\end{array}$ & 1559 & Outside protected area
\end{tabular}

